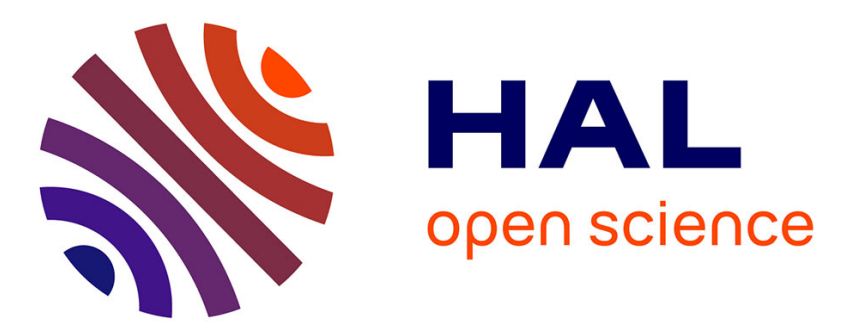

\title{
Solvato Modulation of the Magnetic Memory in Isotopically Enriched Erbium Polyoxometallate
}

Olivier Cador, Jessica Flores Gonzalez, Vincent Montigaud, Vincent Dorcet, Kevin Bernot, Boris Le Guennic, Fabrice Pointillart

\section{- To cite this version:}

Olivier Cador, Jessica Flores Gonzalez, Vincent Montigaud, Vincent Dorcet, Kevin Bernot, et al.. Solvato Modulation of the Magnetic Memory in Isotopically Enriched Erbium Polyoxometallate. Chemistry - A European Journal, 2021, 27 (39), pp.10160-10168. 10.1002/chem.202100953 . hal-03247461

\author{
HAL Id: hal-03247461 \\ https://hal.science/hal-03247461
}

Submitted on 15 Jun 2021

HAL is a multi-disciplinary open access archive for the deposit and dissemination of scientific research documents, whether they are published or not. The documents may come from teaching and research institutions in France or abroad, or from public or private research centers.
L'archive ouverte pluridisciplinaire $\mathbf{H A L}$, est destinée au dépôt et à la diffusion de documents scientifiques de niveau recherche, publiés ou non, émanant des établissements d'enseignement et de recherche français ou étrangers, des laboratoires publics ou privés. 
WILEY-VCH

\title{
Solvato Modulation of the Magnetic Memory in Isotopically Enriched Erbium Polyoxometallate
}

\author{
Jessica Flores Gonzalez, ${ }^{[a]}$ Vincent Montigaud, ${ }^{[a]}$ Vincent Dorcet, ${ }^{[a]}$ Kevin Bernot, ${ }^{[a, b]}$ Boris Le \\ Guennic, ${ }^{*[a]}$ Fabrice Pointillart, ${ }^{*[a]}$ and Olivier Cador ${ }^{*[a]}$
}

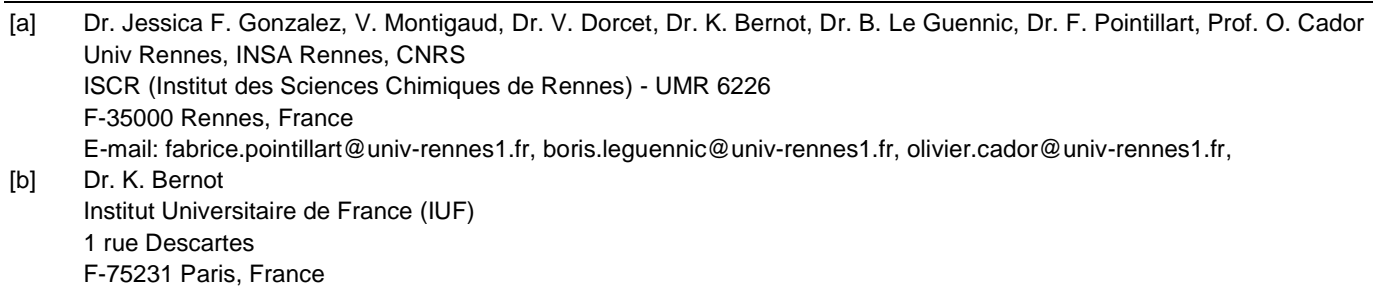

Supporting information for this article is given via a link at the end of the document.

\begin{abstract}
Single-Molecule Magnet (SMM) property is molecular by essence while commonly measured in solid crystalline state. Solvent crystallization molecules are usually neglected in the analysis and interpretation of solid state properties. Solvation/desolvation process in the polyoxometallate(POM)-based $\mathrm{Na}_{9}\left[\mathrm{Er}\left(\mathrm{W}_{5} \mathrm{O}_{18}\right)_{2}\right] \cdot 35 \mathrm{H}_{2} \mathrm{O}$ SMM demonstrates that the dehydrated form relaxes more than 1000 times faster than the initial state while the rehydration process allows the quasi complete recovering of the initial magnetic behaviour. This dehydration process is monitored by Thermogravimetric Analysis (TGA) and temperature dependent X-ray powder diffraction, and rationalized by periodic quantum chemical calculations evidencing the tremendous role of the labile water molecules in the stability of the edifice. Ab-initio calculations highlight that sodium ions localization in the structure drive the magnetic responses. Isotopic enrichment with nuclear spin free $\left({ }^{166} \mathrm{Er}, \mathrm{I}=0\right) \mathrm{Er} \mathrm{r}^{\mathrm{III}}$ ions shows that the relaxation dynamics in the quantum regime depends on the nuclear spin.
\end{abstract}

\section{Introduction}

Almost 30 years ago, the Single-Molecule Magnets (SMMs) were discovered; those molecules which are able to retain the magnetic memory at the molecular scale..$^{[1,2]}$ After this pioneering work, for 10 years, the molecules targeted to be the memory bytes were polynuclear transition metal-based complexes until the emergence of mononuclear-SMMs based on lanthanides. ${ }^{[3]}$ In the latter systems, the magnetic anisotropy, at the origin of the trapping of the atomic magnetic moment in one direction, results from the combination of spin-orbit coupling and crystal field effects. Hundreds of these mononuclear lanthanide-based $\mathrm{SMMs}^{[4-6]}$ have been produced to date with a special dedication to Dy"I, Tb"II and $\mathrm{Er}^{\text {III }}$ based complexes which represent about $90 \%$ of the published examples. ${ }^{[7]}$ Blocking temperatures of these objects, the temperatures below which the magnetic hysteresis is preserved, have recently reached the liquid nitrogen boiling point ${ }^{[8,9]}$ making them potentially adapted to technologic applications such as electronic or spintronic devices. ${ }^{[10-12]}$ Most of the magnetic characterizations of SMMs are performed in the crystalline state (single- or micro-crystals). Investigations are thus performed on a collective and rigid assembly of molecules.
However, as far as the property of the isolated object is concerned, the design of SMM-based devices will require to preserve the SMM property out of the crystalline matrix, for example once grafted on a surface. ${ }^{[13-15]}$ However, the lanthanide-ligand interaction is essentially ionic and so the coordination polyhedron can easily be altered by the environment and adopt various geometries. Such flexibility affords a wide variety of molecules but is a drawback for the tailored control and prediction of the magnetic relaxation of a given molecule.

As a matter of example, some of us recently reported that two polymorphs of octacoordinated Dy"II complexes ${ }^{[16]}$ with very similar coordination and geometries ${ }^{[17]}$ do not relax at the same speed. Similarly, Ln-based SMMs that are water-coordinated show an extreme sensitivity of their magnetic behavior to coordinated-water orientation and $\mathrm{H}$-bond network. ${ }^{[18-21]}$

It is then obvious that solvation/desolvation processes of coordinated solvent dramatically change SMM properties since the coordination number changes and therefore the crystal field splitting. ${ }^{[22-24]}$ More surprisingly desorption and re-adsorption of guest molecules in a porous SMM framework also induces significant modifications of the relaxation processes. ${ }^{[20,21,25-32]}$ These changes can be attributed to: i) subtle atomic displacement ${ }^{[19]}$ that are enough to modify the ground state multiplet splitting and the electronic structure ii) modification of the phonon bath of the magnetic system. Such modification is supposed to modify the thermally activated processes such as Orbach (exponential law) or Raman (power law) and in a less extent, direct (linear law). ${ }^{[33]}$

At very low temperature, the relaxation time is supposed to diverge for thermally activated processes. However, in most cases the relaxation time becomes thermally independent and enters in quantum regime. ${ }^{[4,5]}$ This is the sign of through the barrier process called Quantum Tunnelling of the Magnetisation (QTM) This was evidenced on molecules in the pioneering work of Sessoli et al.[1] and opened new perspectives in the field of quantum computing. ${ }^{[34]}$ For integer quantum number (spin, $S$, or total angular momentum, $\mathcal{J}$ ), modulations of the crystal field can admix $+M_{\lrcorner}$and $-M_{\lrcorner}$components while it is not the case for half integer quantum numbers (Kramers degeneracy). So, formally, no QTM should be observed for Dy'II and Er'II-based ( $J=15 / 2)$ mononuclear SMMs. Additional perturbations must be taken into 
account to allow QTM such as dipolar field (or exchange field) created by surrounding and/or coupling with nuclear spins when nuclear spins exist as well as molecular flexibility as recently hypothesized. [35]

The dipolar field can be, in principle, easily suppressed through dilution of the paramagnetic complex in an isomorphous diamagnetic matrix or dispersed in solvent. These two approaches are a way to clearly evidence the molecular origin of the magnetic relaxation. ${ }^{[36,37]}$

The suppression of hyperfine interactions through isotopic enrichment can be more tedious. For lanthanide ions, the isotopic enrichment covers only few elements. Indeed, neodymium, samarium, gadolinium, dysprosium, erbium and ytterbium are the only lanthanide atoms where hyperfine coupling can be cancelled by isotopic enrichment (Table S1). Furthermore, in the former list only dysprosium and erbium can give rise to SMM behaviour without magnetic dilution in zero external dc field. ${ }^{[7]}$ Some of us have made a commitment in this way and proved that this strategy works in dysprosium-based mononuclear SMMs: the relaxation time of the magnetic moment in the quantum regime becomes longer with the suppression of the nuclear spin at metallic site and shorter when magnetically active nuclei are employed. ${ }^{[38],[16]}$ Similar magnetic trend has been very recently extended to its ytterbium analogue. ${ }^{[39]}$ It appeared thus suitable to extend such investigations to erbium-based mononuclear molecules that behave as SMM in zero field. Few families of Er-SMMs have been reported so far: $\left[\left(\mathrm{Cp}^{*}\right) \operatorname{Er}(\mathrm{COT})\right]$ $\left(\left(\mathrm{Cp}^{*}=\right.\right.$ pentamethylcyclopentadienide;

COT=cyclooctatetraenide ${ }^{[40]},\left[\operatorname{Er}(\mathrm{COT})_{2}\right]^{[,[41,42]}\left[\mathrm{Er}\left\{\mathrm{N}\left(\mathrm{SiMe}_{3}\right)_{2}\right\}\right],{ }^{[43]}$ $\left[\mathrm{Er}\left\{\mathrm{N}\left(\mathrm{SiMe}_{3}\right)_{2}\right\}_{3} \mathrm{Cl}\right]^{-[44]}$ and the older $\left[\operatorname{Er}\left(\mathrm{W}_{5} \mathrm{O}_{18}\right)_{2}\right]^{9-9-9-[45,46]}$ In the latter example, the chemical formula of the crystalline material is $\mathrm{Na} 9\left[\mathrm{Er}\left(\mathrm{W}_{5} \mathrm{O}_{18}\right)_{2}\right] \cdot 35 \mathrm{H}_{2} \mathrm{O}$ where the $\left(\mathrm{W}_{5} \mathrm{O}_{18}\right)^{6-}$ is a polyoxometallate (POM). Amongst the thirty-five water molecules some are free and some are coordinated to one or two $\mathrm{Na}^{+}$cations. It offers a rather unique opportunity to investigate possible dehydration/rehydration processes on Er-SMM that can be isotopically enriched. In the following, the synthesis, the crystal structure and the magnetic properties of the solvated form are briefly recalled. Then, the magnetic properties of the isotopically enriched crystalline form are presented with their evolution as a function of the hydration rate.

\section{Results and Discussion}

\section{Synthesis and crystal structure}

\section{Synthetic procedures}

$\mathrm{Na}_{9}\left[\mathrm{Er}\left(\mathrm{W}_{5} \mathrm{O}_{18}\right)_{2}\right] \cdot 35 \mathrm{H}_{2} \mathrm{O}\left(\mathrm{Er} \cdot 35 \mathrm{H}_{2} \mathrm{O}\right)$ was prepared following a modified version of an already published method (see experimental section). ${ }^{[45,47]}$

\section{Crystal structure}

The crystal structure of $\mathbf{E r} \cdot \mathbf{3 5} \mathrm{H}_{2} \mathrm{O}$ has been resolved on singlecrystal by $\mathrm{X}$-ray diffraction (see Supporting Information). $\mathrm{Er} \cdot 35 \mathrm{H}_{2} \mathrm{O}$ crystalizes in the triclinic $\mathrm{P}-1\left(\mathrm{~N}^{\circ} 2\right)$ space group (Table
S2) and the crystal structure is identical to the one published by M. A. AIDamen et al. ${ }^{[45,46]}{ }^{166} \mathrm{Er} \cdot 35 \mathrm{H}_{2} \mathrm{O}$ and ${ }^{167} \mathrm{Er} \cdot 35 \mathrm{H}_{2} \mathrm{O}$ are isostructural so only the unit cells have been collected (Table S3). The crystal structure is briefly recalled hereafter. The anionic complex consists of Er"II coordinated to two anionic moieties of lacunar polyoxometallate $\left[\mathrm{W}_{5} \mathrm{O}_{18}\right]^{6-}$ (Figure $\mathrm{S} 1$ ). This anionic cluster is surrounded by a network of $\mathrm{Na}^{+}$cations and water molecules. The nine $\mathrm{Na}^{+}$ions balance the negative charge of the complex. Water molecules are bounded to these cations to form octahedral environments except for one of $\mathrm{Na}^{+}$that lies in a square pyramidal environment. Three $\mathrm{Na}^{+}$ions are directly bonded to oxygen atoms of the cluster. The two tetradentate $\left[\mathrm{W}_{5} \mathrm{O}_{18}\right]^{6-}$ ligands generate a $\mathrm{O}_{8}$ coordination sphere around the $\mathrm{Er}^{3+}$ cation in a remarkably symmetric square antiprism $\left(\mathrm{D}_{4 \mathrm{~d}}\right.$, SHAPE analysis: ${ }^{[17]} \mathrm{CShM}_{\text {SAPR- } 8}=0.079$, $\mathrm{CShM}_{\mathrm{BTPR}-8}=2.264$ and $\mathrm{CShM}_{\mathrm{TDD}-8}=2.452$ ) (Figure S1). The average distance between the two mean planes of the coordinated oxygen atoms of each tetradentate ligand is equal to $2.50(4) \AA$ while the distance between neighbouring oxygen is $\sim 2.85 \AA$. Thus, in first approximation, the electronic density generated by the first coordination sphere may be smaller along the POM-Er-POM axis than in the perpendicular plane passing through the erbium ion. The shortest distance between two neighbouring $\mathrm{Er}^{\mathrm{III}}$ ions is 12.8 $\AA$ that insures very weak interactions between $4 f$ spin carriers. Water molecules are depicted on Figure 1. Three different types of water molecules are present in the crystal lattice. Three of them are free, fifteen act as terminal coordinated water molecules and finally seventeen bridge sodium ions (Figure $\mathrm{S} 2$ ). A strong $\mathrm{H}$-bond network stabilizes the structure $(\mathrm{O} \cdots \mathrm{O}$ distances range from 2.6 to $3.0 \AA$ ) (Figure S3).

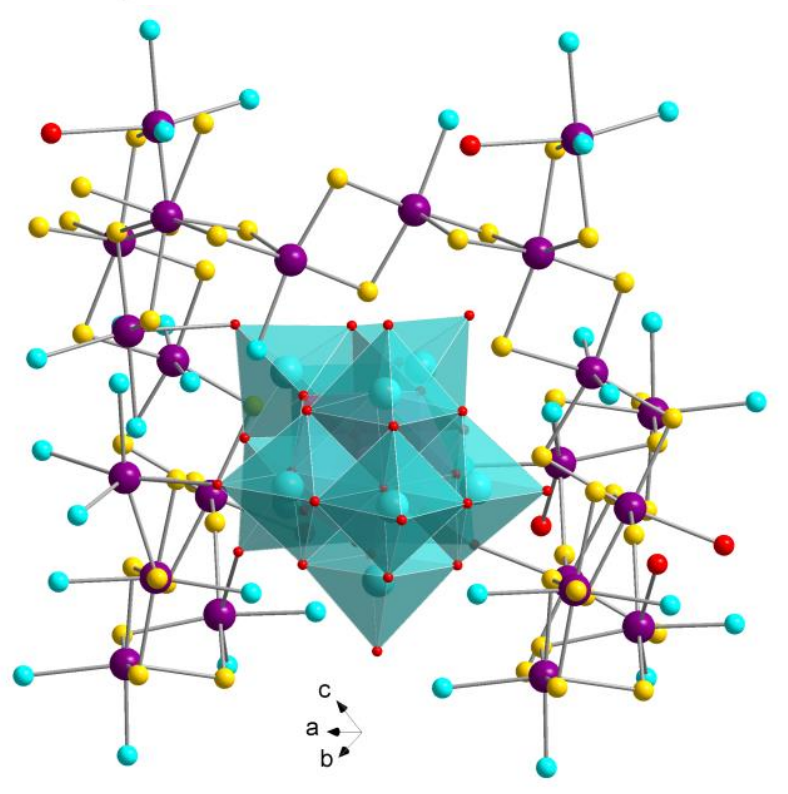

Figure 1. Representation of the lattice of sodium cations (purple) and water molecules (hydrogen atoms and free water molecules are omitted). Oxygen atoms of POMs are in red, terminal water molecules in cyan and bridging in gold.

\section{Thermal analyses}

Thermogravimetric and thermo-differential analyses (TGA/DTA) have been performed in order to characterize the lability of the 
various water molecules in $\mathbf{E r} \cdot \mathbf{3 5} \mathrm{H}_{2} \mathrm{O}$. Two sharp weight loss are found and centred at $62^{\circ} \mathrm{C}$ and $106^{\circ} \mathrm{C}$ corresponding to the loss of 21 and 8 water molecules respectively (Figure 2). Above $106^{\circ} \mathrm{C}$ a continuous weight loss is observed to reach the dehydrated form of the complex. It can be noticed that the dehydrated sample recovers its initial weight if let in air overnight and is then called Er.RH for "rehydrated". Different TGA/DTA cycles after rehydration $\left(\mathrm{RT}-140^{\circ} \mathrm{C}\right)$ are almost perfectly superimposed (Figure S4). This let us think that the core of the complex is still preserved up to $140^{\circ} \mathrm{C}$ and that water release/uptake does not alter the core of the POM. Temperature dependant X-ray powder diffraction (TDXD) has been performed from $25^{\circ} \mathrm{C}$ up to $200^{\circ} \mathrm{C}$ (Figure 3). It shows a strong evolution of the diffractograms and a progressive loss of crystallinity as temperature is raised. At room temperature the experimental diffractogram does not match the simulated one from crystal structure at $-123^{\circ} \mathrm{C}$ (Figure S5), especially below $2 \theta=15^{\circ}$, that corresponds to diffracting planes above $\approx 6 \AA$. This indicates a strong influence of the solvated water molecules on the organization of the POM in the crystal packing. Then, for higher temperatures than $115^{\circ} \mathrm{C}$ the system completely loses its crystallinity. As expected from TGA analyses, the crystallinity can be recovered after rehydration at room temperature in moist air (Figure S6). However, strong dependence of crystal structure upon release/uptake of solvated molecule is once again observed.

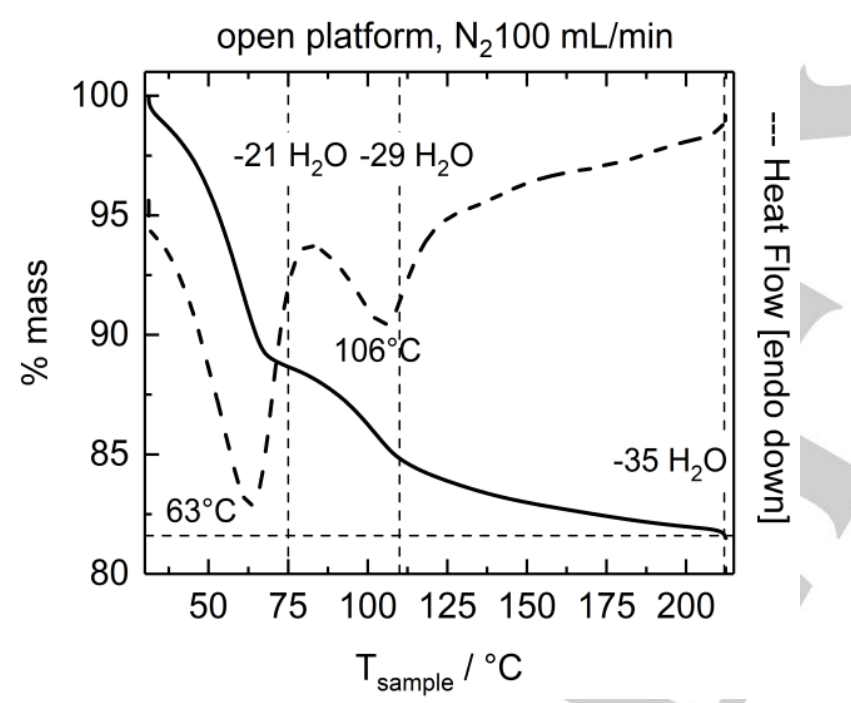

Figure 2. Temperature dependence of the loss of mass (\%, continuous black line) and heat flow for $\mathrm{Er} \cdot 35 \mathrm{H}_{2} \mathrm{O}$ (dashed black line). The vertical dashed lines correspond to the different temperature segments considered for the evolution of the mass loss: $30-75^{\circ} \mathrm{C}\left(\Delta \mathrm{m}=11.3 \%, \mathrm{Er} \cdot 14 \mathrm{H}_{2} \mathrm{O}\right) ; 75-110^{\circ} \mathrm{C}(\Delta \mathrm{m}=3.9 \%$, $\left.\mathrm{Er} \cdot 6 \mathrm{H}_{2} \mathrm{O}\right)$; and $110-212{ }^{\circ} \mathrm{C}\left(\Delta \mathrm{m}=3.3 \%, \mathrm{Er} \cdot \mathrm{OH}_{2} \mathrm{O}\right)$. The horizontal dashed line shows the limit calculated for the fully dehydrated sample.

\section{Theoretical approach to the dehydration process}

All the structure optimizations were carried out using periodic Density Functional Theory (details in Experimental Section). Starting from the optimized structure of $\mathrm{Er} \cdot 35 \mathrm{H}_{2} \mathrm{O}$ three models were generated removing step-by-step the weakest bonding water molecules: $\mathrm{Er} \cdot \mathbf{2} \mathrm{OH}_{2} \mathrm{O}, \mathrm{Er} \cdot \mathbf{6} \mathrm{H}_{2} \mathrm{O}$ and finally the fully dried system, $\mathbf{E r} \cdot \mathbf{O H}_{2} \mathrm{O}$. These stages correspond to the loss of free and terminal water molecules $\left(\mathrm{Er} \cdot \mathbf{2} \mathbf{2} \mathrm{H}_{2} \mathbf{O}\right)$, weakly bridging molecules
$\left(\mathrm{Er} \cdot 6 \mathrm{H}_{2} \mathrm{O}\right)$ and finally strongly bridging molecules $\left(\mathrm{Er} \cdot \mathrm{OH}_{2} \mathrm{O}\right)$ after optimization of the structure at each step of dehydration (Figure 4).

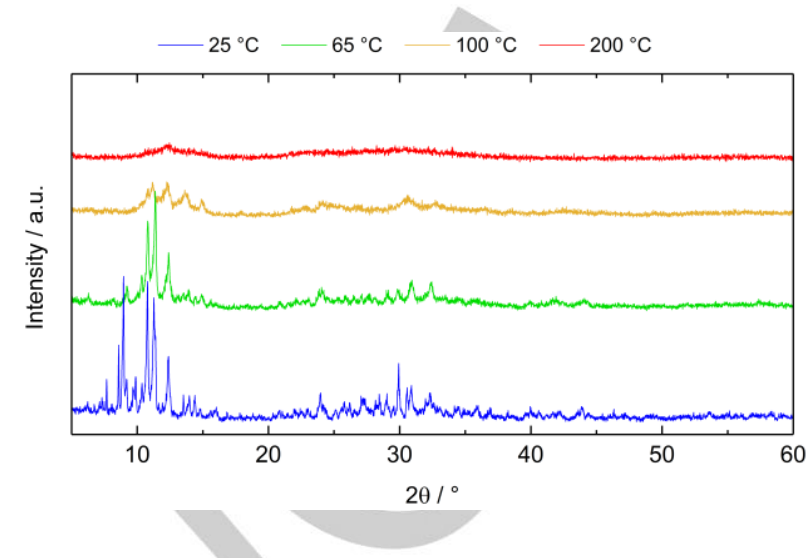

Figure 3. Selected diffractograms from the Temperature Dependent powder $\mathrm{X}$ ray Diffraction (TDXD) analysis of $\mathbf{E r} \cdot 35 \mathrm{H}_{2} \mathrm{O}$.

Table 1. Evolution of the computed unit cell parameters at various stages of the dehydration process.

\begin{tabular}{lccccccc} 
Compound & $\mathrm{a} / \AA$ & $\mathrm{b} / \AA$ & $\mathrm{c} / \AA$ & $\alpha /{ }^{\circ}$ & $\beta /{ }^{\circ}$ & $\gamma /{ }^{\circ}$ & $\mathrm{V} / \AA^{3}$ \\
$\mathrm{Er} \cdot \mathbf{3 5} \mathrm{H}_{2} \mathrm{O}$ & 12.40 & 12.94 & 20.37 & 81.6 & 72.3 & 88.2 & 3080 \\
$\mathrm{Er} \cdot \mathbf{2 0 \mathrm { H } _ { 2 } \mathrm { O }}$ & 11.83 & 12.12 & 18.61 & 81.8 & 67.9 & 83.2 & 2440 \\
\hline $\mathrm{Er} \cdot \mathbf{6} \mathrm{H}_{2} \mathrm{O}$ & 11.54 & 10.83 & 17.19 & 77.9 & 66.3 & 94.6 & 1890 \\
$\mathrm{Er} \cdot \mathrm{OH}_{2} \mathrm{O}$ & 11.15 & 12.18 & 15.83 & 79.9 & 66.7 & 113.2 & 1668
\end{tabular}

The evolution of the computed unit cell parameters of the optimized structures is reported in Table 1. The gradual loss of water in the crystal causes a contraction of the unit cell mainly in the $b c$ plane, with a reduction of $16 \%$ along $b$ and $c$ between Er. $35 \mathrm{H}_{2} \mathrm{O}$ and $\mathrm{Er} \cdot 6 \mathrm{H}_{2} \mathrm{O}$, while $a$ is reduced by $7 \%$ in the same interval. Such contraction coupled with the distortion of the unit cell angles (variation of 5,8 and $7 \%$ for $\alpha, \beta$ and $\gamma$, respectively) lead to a reduction of almost $40 \%$ of the unit cell volume when only bridging molecules are present (Figure S7). At the molecular level, the $\left[\mathrm{Er}\left(\mathrm{W}_{5} \mathrm{O}_{18}\right)_{2}\right]^{9-}$ unit is also affected by the loss of water molecules (Figure 4). More specifically, the dehydration of the compound generates a deformation of the $\mathrm{ErO}_{8}$ coordination sphere. The SHAPE analysis of the optimized $\mathrm{ErO}_{8}$ coordination polyhedron reveals an increasing distortion from the ideal $D_{4 d}$ geometry upon water removal (Table S4) before breaking down when all water molecules are gone $\left(\mathbf{E r} \cdot \mathbf{O} \mathrm{H}_{2} \mathbf{O}\right)$. Since the $\left[\mathrm{Er}\left(\mathrm{W}_{5} \mathrm{O}_{18}\right)_{2}\right]^{9-}$ unit is not affected during the first stages of the dehydration mechanism, the cell variations are attributed to a reorganisation of both the water and cation subnetworks (i.e. ionic interactions). The space created by the loss of water allows the sodium cations and remaining water molecules to move within the crystal and the competition between attractive $\left(\mathrm{Na}^{+}-\mathrm{O}^{2-}\right)$ and repulsive $\left(\mathrm{Na}^{+}-\mathrm{Na}^{+}\right)$ionic interactions lead to a reduction of the distances between the $\mathrm{ErO}_{8}$ coordination sphere and the first $\mathrm{Na}^{+}$ neighbours. Such behaviour is observed until all water molecules are removed. In the dried compound, the breaking of the Er unit is due to both the absence of bridging water molecules (the last few molecules that ensure the cohesion of the two $\left(\mathrm{W}_{5} \mathrm{O}_{18}\right)^{6-}$ 
fragments around the $\mathrm{Er}$ centre) and the entering of $\mathrm{Na}^{+}$ions in the coordination sphere of the lanthanide.

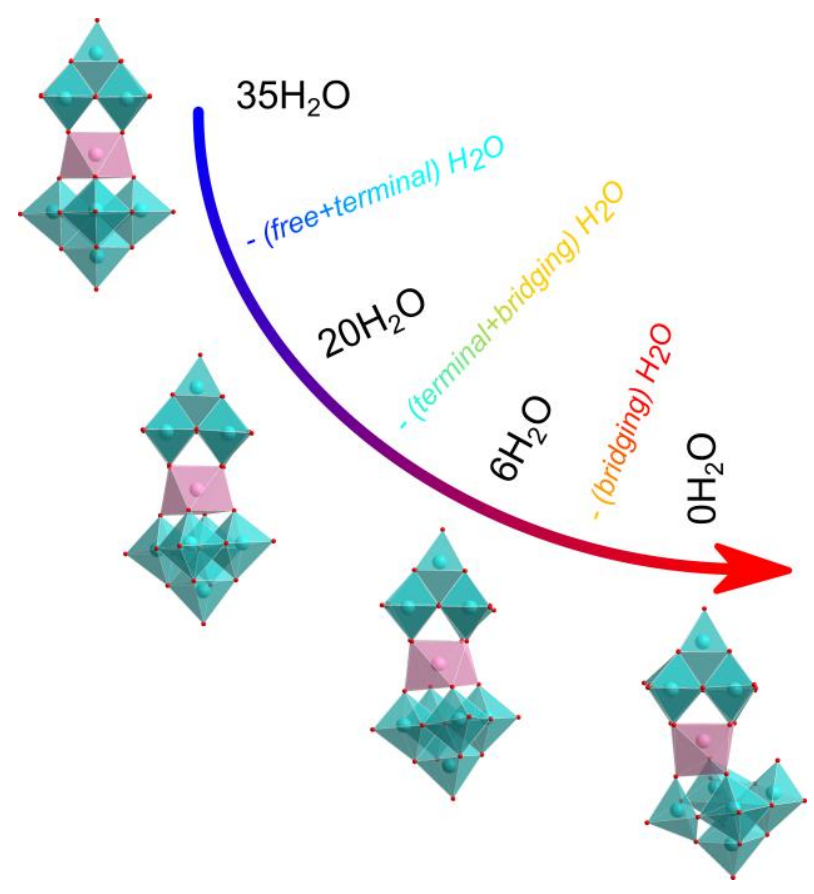

Figure 4. Representation of the optimized structure of the $\left[\mathrm{Er}\left(\mathrm{W}_{5} \mathrm{O}_{10}\right)_{2}\right]^{9-}$ complex following the departure of the different water molecules that are indicated with colour code of Figures 1 and S2.

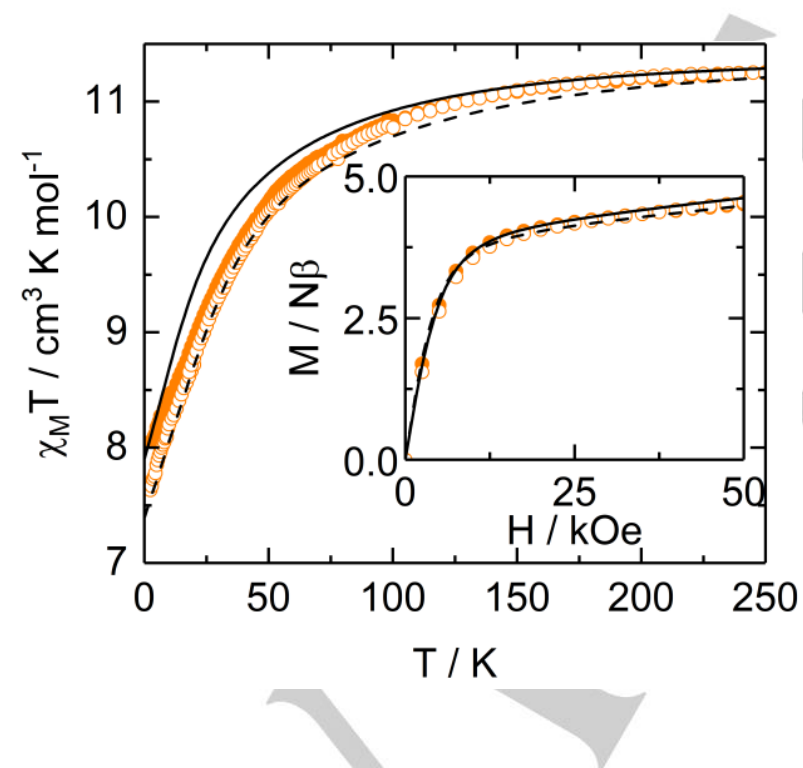

Figure 5. Thermal variation of $\chi_{\mathrm{MT}}$ for ${ }^{166} \mathrm{Er} \cdot 35 \mathrm{H}_{2} \mathrm{O}$ (full orange dots) and ${ }^{166} \mathrm{Er} \cdot \mathrm{XH}_{2} \mathrm{O}$ (empty orange dots). Inset: magnetization curves at $2 \mathrm{~K}$. Full and dashed black lines correspond to the calculated curves from quantum calculations for ${ }^{166} \mathrm{Er} \cdot 35 \mathrm{H}_{2} \mathrm{O}$ and ${ }^{166} \mathrm{Er} \cdot \mathrm{XH}_{2} \mathrm{O}$, respectively.

\section{Magnetic properties}

\section{Static measurements}

The $\chi_{M} T$ vs. T and M vs. H curves have been measured on a fresh and fully hydrated immobilized single crystals of ${ }^{166} \mathrm{Er} \cdot 35 \mathrm{H}_{2} \mathrm{O}$ sample as well as on the partially dehydrated sample (Figure 5) produced directly in the magnetometer cryostat by pumping at $350 \mathrm{~K}$. The latter sample is called ${ }^{166} \mathrm{Er} \cdot \mathrm{xH}_{2} \mathrm{O}$ with $\mathrm{x}<35$. The water uptake starts at room temperature once removed from the magnetometer in ambient air and is easily monitored on a laboratory balance. Measurements on fresh $\mathrm{Er} \cdot 35 \mathrm{H}_{2} \mathrm{O}$ and ${ }^{167} \mathrm{Er} \cdot 35 \mathrm{H}_{2} \mathrm{O}$ superimpose to the ones of ${ }^{166} \mathrm{Er} \cdot 35 \mathrm{H}_{2} \mathrm{O}$ (Figure S8). According to the previous section, the water molecules are easily released so measurements on fresh samples are performed below $250 \mathrm{~K}$ and without pumping to prevent any loss of water molecules. At $250 \mathrm{~K}$, the $X_{M} T$ values are equal to $11.25 \mathrm{~cm}^{3} \mathrm{~K} \mathrm{~mol}^{-}$ ${ }^{1}$ which is in agreement with the expected value for the free $\mathrm{Er}^{\mathrm{III}}$ $\left({ }^{4} I_{15 / 2}\right.$ multiplet ground state and $\left.g_{J}=6 / 5, X_{M} T=11.48 \mathrm{~cm}^{3} \mathrm{~K} \mathrm{~mol}^{-1}\right)$. $X_{M} T$ vs $T$ curves remain quasi constant on cooling down to $150 \mathrm{~K}$. The depopulation of the crystal field levels causes a progressive and continuous decrease of $X_{M}{ }^{\top}$ down to $2 \mathrm{~K}^{2} 8 \mathrm{~cm}^{3} \mathrm{~K} \mathrm{~mol}^{-1}$ for ${ }^{166} \mathrm{Er} \cdot 35 \mathrm{H}_{2} \mathrm{O}$ and $7.5 \mathrm{~cm}^{3} \mathrm{~K} \mathrm{~mol}^{-1}$ for ${ }^{166} \mathrm{Er} \cdot \mathrm{XH}_{2} \mathrm{O}$. At this temperature, the magnetization curves do not saturate with a slight linear increase of the magnetization above $20 \mathrm{kOe}(4.59 \mathrm{~N} \beta$ at $50 \mathrm{kOe}) .{ }^{166} \mathrm{Er} \cdot 35 \mathrm{H}_{2} \mathrm{O}$ crystallizes in the $\mathrm{P}-1$ space group with one crystallographic metal site per unit cell so single-crystal angular-resolved magnetometry can be easily carried out. The angular dependence of the magnetization was measured at $2 \mathrm{~K}$ and at $1 \mathrm{kOe}$ in three orthogonal planes of an oriented single crystal (Figure S9). $X_{M} T$ was then fitted (Figure S10) with:

$\chi_{M} T=M T / H=\chi_{\alpha \alpha} \cos ^{2} \theta+\chi_{\beta \beta} \sin ^{2} \theta+2 \chi_{\alpha \beta} \sin \theta \cos \theta$ where $\alpha$ and $\beta$ are the directions $\mathrm{X}, \mathrm{Y}$ and $\mathrm{Z}$ in a cyclic permutation and $\theta$ is the angle between $H$ and $\alpha$. Diagonalization of the susceptibility matrix provides main axes which in the effective spin $1 / 2$ framework give $g_{x x}=4.29, g_{y y}=5.45$ and $g_{z z}=14.56$. This reveals a relatively strong Ising character of the magnetic anisotropy since the pure Ising state for Er ${ }^{\text {III }}$ multiplet ground state corresponds to $g_{x x}=g_{y y}=0$ and $g_{z z}=18$. The $g_{z}$ orientation in the molecular frame is given on Figure $\mathrm{S} 1$. It is relatively close $\left(11.6^{\circ}\right)$ to the pseudo fourfold axis of the molecule.

$A b$ initio wavefunction-based calculations (see Experimental Section for details) have been performed on models extracted

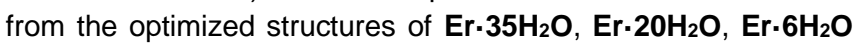
and $\mathrm{Er} \cdot \mathrm{OH}_{2} \mathrm{O}$ (Figure S11). For $\mathrm{Er} \cdot \mathbf{3 5} \mathrm{H}_{2} \mathrm{O}$, the computed ground state magnetic anisotropy is described with $g_{x x}=0, g_{y y}=0.01$ and $\mathrm{g}_{\mathrm{zz}}=15.9$ with an angle between $\mathrm{z}$ (experimental) and $\mathrm{z}$ (calculated) direction of $18.4^{\circ}$. The calculated easy magnetic axis is also close $\left(11.3^{\circ}\right)$ to the pseudo fourfold axis of the $\left[\mathrm{Er}\left(\mathrm{W}_{5} \mathrm{O}_{10}\right)_{2}\right]^{9-}$ unit. ${ }^{[48]}$ The calculated energy spectrum and $\mathrm{g}$ tensors of the ground state multiplet are illustrated in Table S5 while the corresponding wavefunction compositions are given in Table S6. The evolution of the ground state anisotropy is depicted in Figure S12 and translates the gradual degradation of the later with the loss of water molecules. Even though the ground state appears to be mainly of $M_{J}= \pm 13 / 2>$ nature, the vicinity of the first excited state $\left(\Delta=29 \mathrm{~cm}^{-1}\right)$ leads to strong mixing of the wavefunction. ${ }^{[48]}$ The computed $\chi_{M} T$ vs. $T$ and $M$ vs. $H$ are in good agreement with experimental data (Figure 5). The linear increase of the magnetization at high field is due to the mixture with excited states. During the first stages of the dehydration mechanism, the distortion of the coordination sphere polyhedron shows a limited effect on the electronic structure. A small gap between the ground state Kramer Doublet (KD) and the first excited KD state is observed with a strong mixing of the wavefunctions. However for 
Er. $6 \mathrm{H}_{2} \mathrm{O}$, when only bridging water molecules are present, a larger gap $\left(\Delta=50 \mathrm{~cm}^{-1}\right)$ is observed. The degradation of the symmetry of the coordination sphere leads to a stronger mixing of the wavefunction and a degradation of the ground state and first excited anisotropies with an increase of the $g_{x x}$ and $g_{y y}$ terms. The computation of the $\chi_{M} T$ vs. T and $M$ vs. $\mathrm{H}$ curves for $\mathrm{Er} \cdot 6 \mathrm{H}_{2} \mathrm{O}$ shows a good agreement with experimental data (Figure 5) but is not quantitative enough to assess that $\mathrm{x}=6$ in the formulation of ${ }^{166} \mathrm{Er} \cdot \mathrm{xH}_{2} \mathrm{O}$.
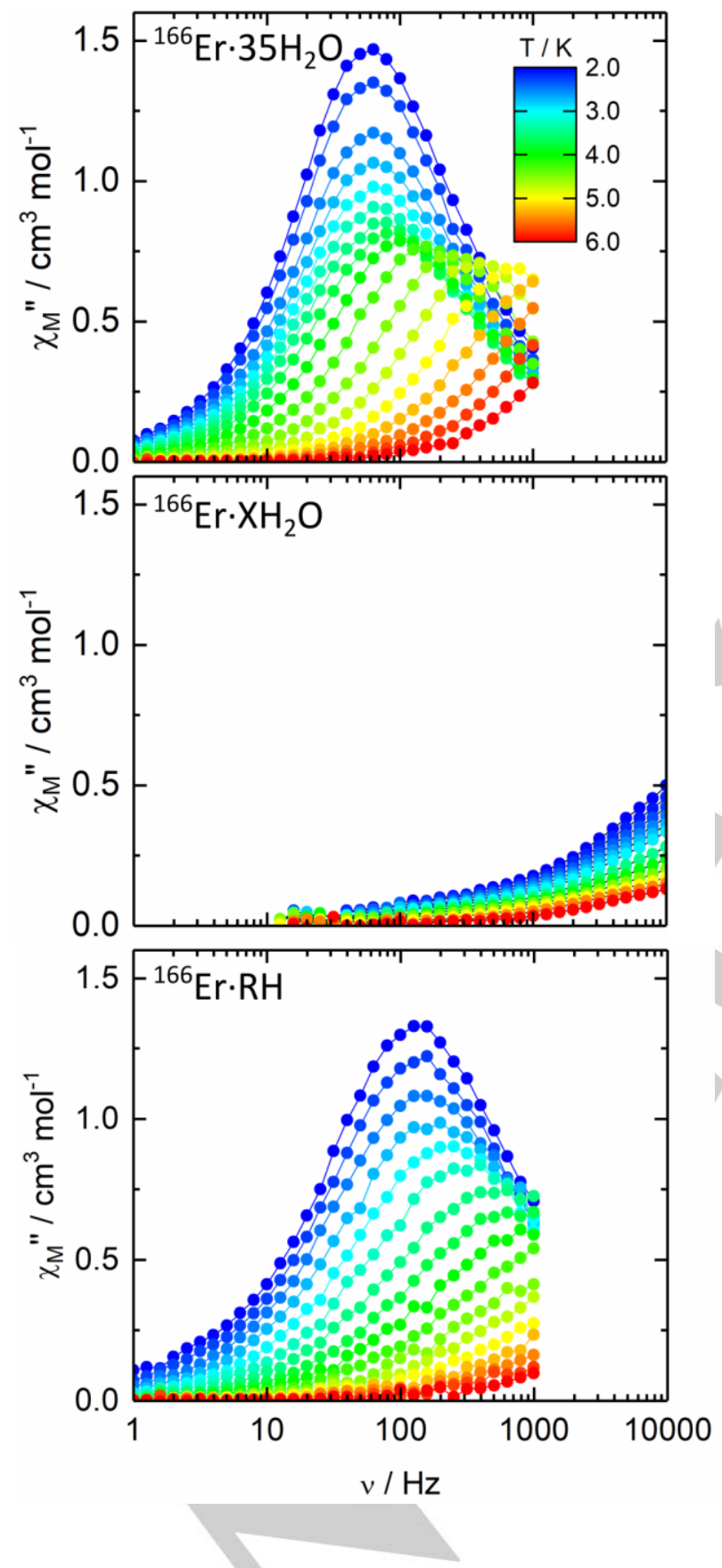

Figure 6. Frequency dependencies of the out-of-phase component, $\chi M^{\prime \prime}$, of the ac susceptibility for three different solvation states of the isotopically enriched ${ }^{166} \mathrm{Er}$ derivative, measured in zero external dc field and at various temperatures.

\section{Dynamic properties}

In the present study we focus first on the dynamic properties of the isotopically enriched ${ }^{166} \mathrm{Er} \cdot 35 \mathrm{H}_{2} \mathrm{O}$, its partially dehydrated phase ${ }^{166} \mathrm{Er} \cdot \mathrm{xH}_{2} \mathrm{O}$ and finally the rehydrated form ${ }^{166} \mathrm{Er} \cdot \mathbf{R H}$. Both in-phase, $\chi_{M}$ ', and out-of-phase, $\chi_{M}{ }^{\prime \prime}$, components of the ac susceptibility have been recorded between 2 and $6 \mathrm{~K}$ in zero external dc field at the three hydration stages of the same and unique sample (Figures 6 and S13). The frequency dependence of $\chi_{\mathrm{M}}$ " undoubtedly attests the presence of SMM behaviour, like in the natural form reported by AIDamen et al...46] The second point that is obvious is the extreme sensitivity of the SMM behaviour with respect to the solvation. Indeed, the dehydration process, even incomplete, shifts the relaxation rate to higher frequencies than $10 \mathrm{kHz}$ (out of the investigation window). The initial relaxation features are partially recovered after air exposure. Partially, means that maxima on the $\chi_{\mathrm{M}}$ " vs. $v$ curves are not exactly at the same frequencies at $2 \mathrm{~K}: 63$ vs. $125 \mathrm{~Hz}$ and the maxima of $\chi_{\mathrm{M}}$ " are found at 1.47 vs. $1.33 \mathrm{~cm}^{3} \mathrm{~mol}^{-1}$ for ${ }^{166} \mathrm{Er} \cdot 35 \mathrm{H}_{2} \mathrm{O}$ and ${ }^{166} \mathrm{Er} \cdot \mathrm{RH}$ respectively. This flattening and high frequency shift can be quantified with the help of extended Debye model (Supporting Information, Figure S14, Tables S7 and S8). In this frame, the low and high frequencies limits are comparable for both solvated forms but the distribution of the relaxation time, estimated through parameter $\alpha$, is much more important for the rehydrated sample (Tables S7 and S8) which justify the lower $\chi_{M}$ " intensity for ${ }^{166} \mathrm{Er} \cdot \mathbf{R H}$ than the one for ${ }^{166} \mathrm{Er} \cdot \mathbf{3 5 H}_{2} \mathrm{O}$. This increase of the distribution is not astonishing since the initial state is not fully recovered during rehydration process and that some portions of the sample could be identical to the initial state from a crystallographic point of view. It must be mentioned as well that the distribution of the relaxation times is relatively narrow $(\alpha<0.14)$ for the initial state of this isotopically enriched material. The temperature dependence of the relaxation times for both hydrated and rehydrated forms is represented on Figure S15. The thermal behavior for ${ }^{166} \mathrm{Er} \cdot \mathbf{3 5} \mathrm{H}_{2} \mathrm{O}$ is easily reproduced with a combination of an Orbach and a thermally independent process $\left(\tau^{-1}=\tau_{\uparrow 1^{-1}}+\tau_{0}\right.$ $\left.{ }^{1} \exp \left(-U_{\text {eff }} / k T\right)\right)$. The best fit is obtained with $\tau_{0}=9(3) \times 10^{-9} \mathrm{~s}$, $\tau T=1.17(4) \times 10^{-3} \mathrm{~s}$ and $U_{\text {eff }}=36(2) \mathrm{cm}^{-1}$. The energy barrier, $U_{\text {eff, }}$, is relatively close to the calculated gap between the ground and the first excited state $\left(29 \mathrm{~cm}^{-1}\right)$ and also close to the value reported by AIDamen et al. in 2008 for the natural derivative $\left(38 \mathrm{~cm}^{-1}\right)$. $^{[46]}$ Dynamic magnetic properties of $\mathbf{E r} \cdot \mathbf{3 5} \mathrm{H}_{2} \mathrm{O}$ were also investigated (Figure S16) and compared to the one of ${ }^{166} \mathrm{Er} \cdot{ }^{35} \mathrm{H}_{2} \mathrm{O}$ (Figures 6 and $\mathrm{S13}$ ). They are hopefully nearly identical since the natural element $\mathrm{Er}$ is composed at $77 \%$ of nuclear spin free isotopes like ${ }^{166} \mathrm{Er}$. Then, at $2 \mathrm{~K}$, the maximum of the $\chi_{\mathrm{M}}$ " vs. $v$ curve occurs also at $63 \mathrm{~Hz}$ but with a smaller amplitude $\left(1.11 \mathrm{~cm}^{3} \mathrm{~mol}^{-1}\right)$ than for ${ }^{166} \mathrm{Er} \cdot 35 \mathrm{H}_{2} \mathrm{O}$. The peaks looks broader and this can be numerically visualized through the parameter $\alpha$ in the extended Debye model that is almost multiplied by two in the natural form (Table S7 vs Table S9) but only in the quantum regime. At the meantime, the relaxation time in the whole temperature window is slightly affected. For both ${ }^{166} \mathrm{Er} \cdot 35 \mathrm{H}_{2} \mathrm{O}$ and $\mathrm{Er} \cdot 35 \mathrm{H}_{2} \mathrm{O}$ the temperature variations of the relaxation time are very similar and described with nearly identical parameters $\left(\tau_{0}=9(4) \times 10^{-9} \mathrm{~s}\right.$, $\tau_{\mathrm{T} I}=2.07(4) \times 10^{-3} \mathrm{~s}$ and $U_{\text {eff }}=35(2) \mathrm{cm}^{-1}$ for Er $\cdot 35 \mathrm{H}_{2} \mathrm{O}$, Figure S17). At this stage, ${ }^{167} \mathrm{Er} \cdot 35 \mathrm{H}_{2} \mathrm{O}$ has been synthesized since ${ }^{167} \mathrm{Er}$ isotope represents $23 \%$ of natural erbium but is the only one with non-zero nuclear spin. This isotopologue has been thoroughly investigated ten years ago by F. Luis et al.[49] The temperature dependence of the ac susceptibility signals are represented on Figure S18. Clearly, the behaviour in the quantum regime (below 
$4 \mathrm{~K}$ ), while reproducible, differs from ${ }^{166} \mathrm{Er} \cdot 35 \mathrm{H}_{2} \mathrm{O}$ with a broadening of the signals. This behaviour is confirmed in the 2 to $6 \mathrm{~K}$ temperature range by the reconstruction of the natural Er. $35 \mathrm{H}_{2} \mathrm{O}$ from $77 \%$ of ${ }^{166} \mathrm{Er} \cdot 35 \mathrm{H}_{2} \mathrm{O}$ and $23 \%$ of ${ }^{167} \mathrm{Er} \cdot 35 \mathrm{H}_{2} \mathrm{O}$ (Figures 7 and S19).

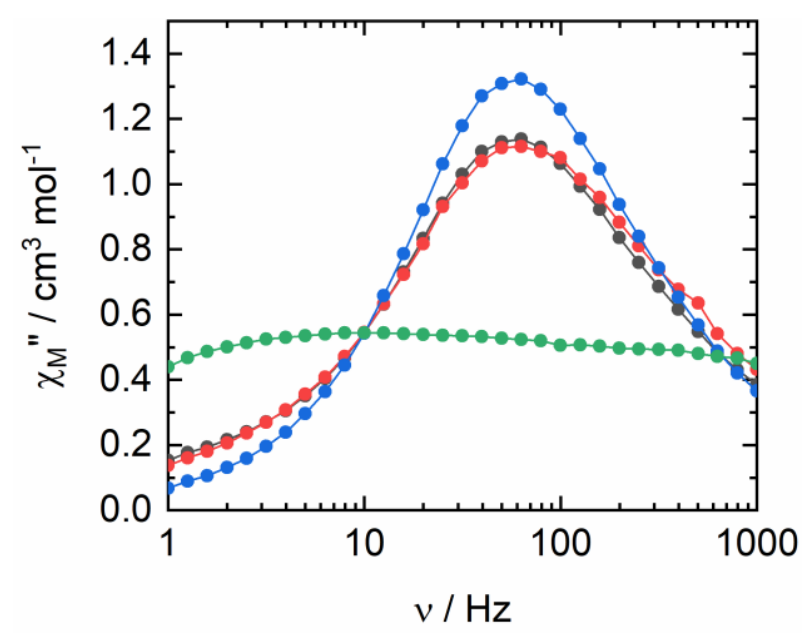

Figure 7. Frequency dependencies of the out-of-phase component, $\chi_{\mathrm{M}}$ ", of the ac susceptibility (in zero external dc field and at $2 \mathrm{~K}$ ) for $\mathbf{E r} \cdot \mathbf{3 5} \mathrm{H}_{2} \mathrm{O}$ (red), ${ }^{166} \mathrm{Er} \cdot 35 \mathrm{H}_{2} \mathrm{O}$ (blue), ${ }^{167} \mathrm{Er} \cdot 35 \mathrm{H}_{2} \mathrm{O}$ (green) and reconstructed from $77 \%$ of ${ }^{166} \mathrm{Er} \cdot 35 \mathrm{H}_{2} \mathrm{O}$ and $23 \%$ of ${ }^{167} \mathrm{Er} \cdot 35 \mathrm{H}_{2} \mathrm{O}$ (black).

The hysteresis loops of ${ }^{166} \mathrm{Er} \cdot 35 \mathrm{H}_{2} \mathrm{O},{ }^{166} \mathrm{Er} \cdot \mathrm{XH}_{2} \mathrm{O}$ and ${ }^{166} \mathrm{Er} \cdot \mathrm{RH}$ are represented in Figure 8. It evidences butterfly type loops centred at the origin for the initial $\left({ }^{166} \mathrm{Er} \cdot 35 \mathrm{H}_{2} \mathrm{O}\right)$ and the rehydrated $\left({ }^{166} \mathrm{Er} \cdot \mathbf{R H}\right)$ phases. The contraction at zero field is entirely due to the relatively fast relaxation at 0 Oe. For ${ }^{166} \mathrm{Er} \cdot 35 \mathrm{H}_{2} \mathrm{O}$ the coercive field is maximum at $1.375 \mathrm{kOe}$ and equal to $2.25 \mathrm{kOe}$. These values are equal to $1.375 \mathrm{kOe}$ and 1.75 $\mathrm{kOe}$ for ${ }^{166} \mathrm{Er}$. RH indicating that the rehydration process does not lead to the full recovery of the initial state in agreement with X-ray powder diffraction observations, vide supra. The dehydration process annihilates the in-field memory effect, i.e. the loop is closed at any applied field for ${ }^{166} \mathrm{Er} \cdot \mathbf{x H}_{2} \mathrm{O}$.

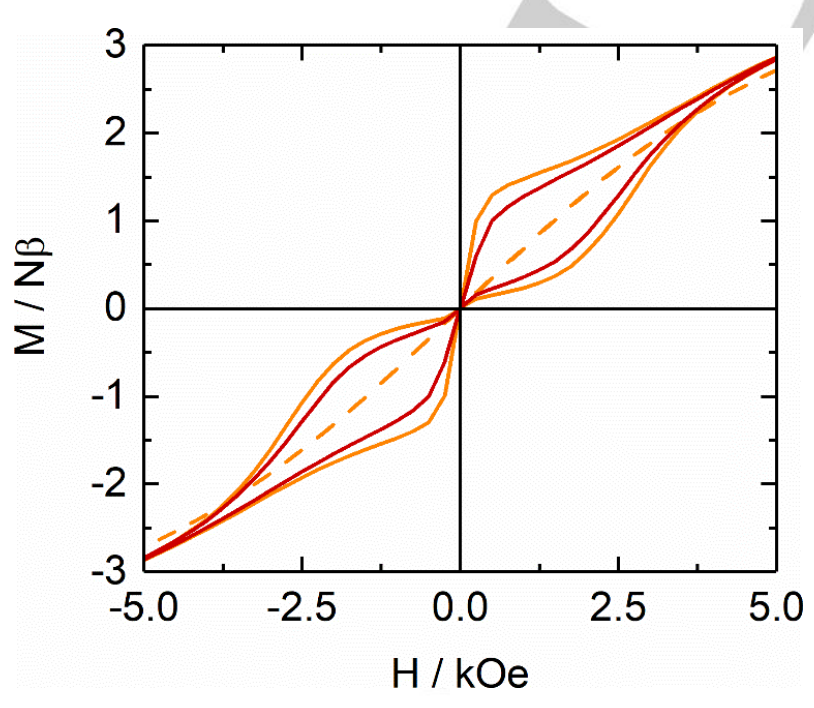

Figure 8. Hysteresis loops of ${ }^{166} \mathrm{Er} \cdot 35 \mathrm{H}_{2} \mathrm{O}$ (orange full line), ${ }^{166} \mathrm{Er} \cdot \mathrm{xH}_{2} \mathrm{O}$ (orange dotted line) and ${ }^{166} \mathrm{Er} \cdot \mathbf{R H}$ (bordeaux full line) measured at $2 \mathrm{~K}$ at sweep rate of $16 \mathrm{Oe} \mathrm{s}^{-1}$.

\section{Conclusion}

The influence of hydration on the Single-Molecule Magnet properties of an Er-based polyoxometallate compound has been investigated. We have shown through dynamic magnetic measurements that the release of solvated water molecules from the bulk almost completely annihilates its SMM properties. Quantum chemical calculations shed light on the dehydration mechanism and evidenced the reorganization of the sodium counter ions in the vicinity of the complex. The resulting distortion of the coordination polyhedra of the lanthanide ion led to a deterioration of the magnetic anisotropy. This explains the differences between the SMM behaviour of the hydrated and rehydrated complexes. The dehydrated form does not behave as a magnet while the hysteresis loops are opened in field on the hydrated forms. This sponge-like behaviour produces waterdriven modifications of SMM behaviour through the release and capture of water.

We also investigated isotopic effects by looking at the nuclear spin of erbium since ${ }^{166} \mathrm{Er}$ is nuclear spin free while ${ }^{167} \mathrm{Er}$ possesses a nuclear spin of $7 / 2$. On one hand, the enriched material with ${ }^{166} \mathrm{Er}$ behaves nearly the same as the natural one since about $80 \%$ of the natural element is constituted with nuclear spin free atoms. The magnetic behaviour of ${ }^{167} \mathrm{Er} \cdot 35 \mathrm{H}_{2} \mathrm{O}$ remains unclear in the quantum regime. Further isotopic investigations are under progress.

\section{Experimental Section}

Synthesis At first, $\mathrm{ErCl}_{3} \cdot 6 \mathrm{H}_{2} \mathrm{O}$ was formed by dissolving $30 \mathrm{mg}$ of $\mathrm{Er}_{2} \mathrm{O}_{3}$ in $400 \mu \mathrm{L}$ of $37 \% \mathrm{HCl}$ during 30 minutes at $80^{\circ} \mathrm{C}$ with continuous stirring. $1 \mathrm{~mL}$ of distilled water was added and the $\mathrm{pH}$ was adjusted to 3 with $\mathrm{NaOH}$ solution (3 M). Simultaneously, $\mathrm{Na}_{2} \mathrm{WO}_{4} \cdot 2 \mathrm{H}_{2} \mathrm{O}(15.2 \mathrm{mmol}, 5 \mathrm{~g})$ was dissolved in distilled water $(10 \mathrm{~mL})$ with continuous stirring, the $\mathrm{pH}$ was adjusted to 7.2 with acetic anhydride, and the resulting solution was heated up to $90^{\circ} \mathrm{C}$. Then, the former solution was poured dropwise on the erbium chloride solution and hold under vigorous stirring for $1 \mathrm{~h}$. The mixture was filtered quickly and left at room temperature for evaporation for 2 to 4 days. After this period, a mixture with different types of crystals appeared. Recrystallization in hot water $\left(60^{\circ} \mathrm{C}\right)$ affords needled-shaped pale-pink

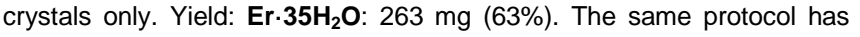
been methodically employed with isotopically enriched ${ }^{\mathrm{A}} \mathrm{Er}_{2} \mathrm{O}_{3}$ starting materials (with $\mathrm{A}=166(96.6 \%)$ and $167(95.3 \%)$ ) purchased from Eurisotop to afford ${ }^{166} \mathrm{Er} \cdot 35 \mathrm{H}_{2} \mathrm{O}$ and ${ }^{167} \mathrm{Er} \cdot 35 \mathrm{H}_{2} \mathrm{O}$. Yields: ${ }^{166} \mathrm{Er} \cdot 35 \mathrm{H}_{2} \mathrm{O}$ $217.4 \mathrm{mg}(52 \%) ;{ }^{167} \mathrm{Er} \cdot 35 \mathrm{H}_{2} \mathrm{O}: 179 \mathrm{mg}(43 \%)$. IR: Er.35 $\mathrm{H}_{2} \mathrm{O}: 3464(\mathrm{~s})$, 2089(w), 1622(m), 1570(w), 1416(w), 934(m), 849(m), 796(w), 710(m), 545(w), 493(w); ${ }^{166} \mathrm{Er} \cdot 35 \mathrm{H}_{2} \mathrm{O}: \quad 3450(\mathrm{~s}), \quad 2096(\mathrm{w}), \quad 1640(\mathrm{~s}), \quad 1565(\mathrm{~m})$, 1416(w), 934(m), 852(s), 804(m), 704(m), 547(w), 499(w); ${ }^{167} \mathrm{Er} \cdot 35 \mathrm{H}_{2} \mathrm{O}$ : 3440(s), 2370(w), 2111(w), 1628(s), 1412(w), 932(s), 848(s), 794(m), 708(s), 542(w), 492(w).

Single-crystal X-ray diffraction. Single crystal of $\mathrm{Er} \cdot 35 \mathrm{H}_{2} \mathrm{O},{ }^{166} \mathrm{Er} \cdot 35 \mathrm{H}_{2} \mathrm{O}$ and ${ }^{167} \mathrm{Er} \cdot 35 \mathrm{H}_{2} \mathrm{O}$ were mounted on a D8 VENTURE Bruker-AXS diffractometer for data collection ( $\mathrm{MoK}_{\alpha}$ radiation source, $\lambda=0.71073 \AA$ ), from the Centre de Diffractométrie X (CDIFX), Université de Rennes 1 ,

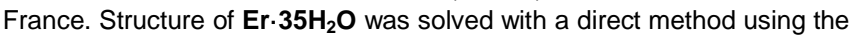
SHELXT program ${ }^{[50]}$ and refined with a full matrix least-squares method on $\mathrm{F}^{2}$ using the SHELXL-14/7 program ${ }^{[51]}$ while the cells are measured for 
${ }^{166} \mathrm{Er} \cdot 35 \mathrm{H}_{2} \mathrm{O}$ and ${ }^{167} \mathrm{Er} \cdot 35 \mathrm{H}_{2} \mathrm{O}$. Crystallographic data are summarized in Tables S2 and S3.

TGA. Thermogravimetric and thermodifferential (TGA/TDA) analyses were performed with a Perkin Elmer Pyris Diamond analyser in a platinum crucible between room temperature and $215^{\circ} \mathrm{C}$ under $\mathrm{N}_{2}$ atmosphere with a heating rate of $5^{\circ} \mathrm{C} \mathrm{min}^{-1}$. Additionally heating/cooling cycles were performed between $25^{\circ} \mathrm{C}$ and $140^{\circ} \mathrm{C}$ with the same heating/cooling rate (Figure S4). All measurements were corrected from the contribution of the sample holders.

TDXD. Thermal Dependant X-Ray Diffraction was performed on a Panalytical X'pert Pro diffractometer, equipped with a X'Celerator detector and an Anton-Parr HTK 1200 oven. Typical recording conditions were $45 \mathrm{kV}, 40 \mathrm{~mA}$ for CuKa $(\lambda=1.542 \AA)$ in $\theta / \theta$ mode. Heating rate of $5^{\circ} \mathrm{C}$. min 1 under $\mathrm{N}_{2}$ atmosphere was used. Each diffractogram was collected at a fixed and stabilized temperature with a 5 min scan in order to avoid kinetic effects and ensure a phase stability during data collection. Simulated pattern was calculated thank to the Mercury program from CCDC.

Magnetic measurements. Magnetic susceptibility data $(2-300 \mathrm{~K})$ were collected on powdered polycrystalline samples on a Quantum Design MPMS-XL SQUID magnetometer under an applied magnetic field of 0.02 T below $20 \mathrm{~K}, 0.2 \mathrm{~T}$ between 20 and $80 \mathrm{~K}$ and finally $1 \mathrm{~T}$ above $80 \mathrm{~K}$ using a pelletized sample in Teflon tape to prevent orientation within the magnetic field. Magnetization isotherm was collected at $2 \mathrm{~K}$. All data were corrected for the contribution of the sample holder and the diamagnetism estimated from Pascal's constants. Alternating current (ac) measurements were performed in the $2-6 \mathrm{~K}$ range in zero external dc field in $1-1000 \mathrm{~Hz}$ range with MPMS-XL SQUID magnetometer and with PPMS equipped with ACMS-II option for frequencies between 1000 and $10000 \mathrm{~Hz}$. Hysteresis loops have been measured at $2 \mathrm{~K}$ with MPMS-XL SQUID magnetometer in hysteresis mode at a sweep rate of $16 \mathrm{Oe} \mathrm{s}^{-1}$.

Computational details. The structure optimisations and unit cell relaxations were performed within the framework of density functional theory (DFT) using the Vienna Ab Initio Software Package (VASP, version 5.4.1). ${ }^{[52-55]}$ The projector-augmented wave (PAW) method was used while the exchange-correlation was treated within the generalized gradient approximation of Perdew, Burke and Ernzerhof (GGA-PBE). ${ }^{[56,57]}$ The van der Walls interactions were corrected using the DFT-D3 method of Grimme. ${ }^{[58]}$ Standard PAW potentials were used for the $\mathrm{O}, \mathrm{Na}$ and $\mathrm{H}$ atoms while $\mathrm{W}$ atoms were described using $\mathrm{W}$ p pv pseudopotential where the $6 \mathrm{~s}$, $5 p$ and $5 d$ electrons are treated as valence. ${ }^{[59,60]}$ The Er atoms were defined with the Er 3 pseudopotential in which the valence consists of the $5 p, 6 s$ and $5 d$ electrons, the $4 f$ electrons are placed in the core. All the calculations were carried on the gamma point with a plane wave cutoff

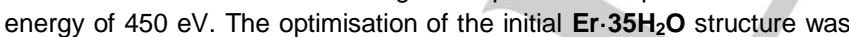
first carried out and evidenced a small contraction of the unit cell frame that falls into the error bar due to the approximations (variations of unit cell parameters $<3 \%$, Table 1). The optimized structure was then used to build a set of models representing different steps during the dehydration process $\left(\mathrm{Er} \cdot \mathbf{2} \mathrm{OH}_{2} \mathrm{O}, \mathrm{Er} \cdot \mathbf{6} \mathrm{H}_{2} \mathrm{O}\right.$ and $\left.\mathrm{Er} \cdot \mathbf{0 H}_{2} \mathrm{O}\right)$. For all optimized structures, the $a b$ initio calculations were carried on a model containing the $\left[\mathrm{Er}\left(\mathrm{W}_{5} \mathrm{O}_{10}\right)_{2}\right]^{9-}$ unit and the closest $\mathrm{H}_{2} \mathrm{O}$ molecules and $\mathrm{Na}^{+}$ions from the Er centre (Figures S7, S11 and S12). The number of water molecules used

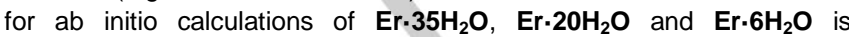
respectively 8,8 and 6 . The optimized coordinates of these molecules are given in Supporting Information. The wavefunction-based calculations were carried using the complete active space self-consistent field (CASSCF) approach, as implemented in the Molcas software package (version 8.2). ${ }^{[61,62]}$ In the first step of the calculations, the static correlation effects arising from the partially filled $4 f$ shell of the $\mathrm{Er}^{\prime \prime \prime}$ ion is computed. The scalar relativistic effects were treated with the second-order DouglasKroll-Hess Hamiltonian in combination with the all-electron atomic natural orbital relativistically contracted (ANO-RCC) basis set from the Molcas library. ${ }^{[63-69]}$ The basis sets contractions used to describe the atoms are the following: [8s7p4d3f2g1h] for Er, [6s5p3d1f] for W and [3s2p1d] for O atoms of the $\left[\mathrm{Er}\left(\mathrm{W}_{5} \mathrm{O}_{10}\right)_{2}\right]^{9-}$ unit. The $\mathrm{Na}^{+}$ions and water molecules were treated as point charges in the calculations. State-averaged calculation (SA-CASSCF) was performed on the basis of the 35 quartet and the 112 doublet spin states arising from the 11 electrons spanning the seven $4 \mathrm{f}$ orbitals (i.e., CAS $(11,7)$ ). The spin-orbit coupling (SOC) was then introduced within a state interaction among the basis of calculated spin free states using the restricted active space state interaction (RASSI) approach. ${ }^{\left[{ }^{70]}\right.}$ Herein the SOC matrix is diagonalized using the calculated 35 quartet and the 89 lowest doublet spin states. The resulting spin-orbit wavefunctions and energies are used to compute the magnetic properties and $g$-tensors of the ground state multiplet following the pseudospin $s=1 / 2$ formalism, as implemented in the Single Aniso routine. ${ }^{[71]}$ Cholesky decomposition of the bielectronic integrals was employed to save disk space and to speed up the calculations. ${ }^{[72]}$

\section{Acknowledgements}

This work was supported by the CNRS, Universite de Rennes 1 the European Commission through the ERC-CoG 725184 MULTIPROSMM (project n. 725184). B.L.G. and V.M. thank the French GENCI/IDRIS-CINES centres for high-performance computing resources. KB Acknowledges Institut Universitaire de France (IUF).

Keywords: Erbium • polyoxometallate $\cdot$ Isotopes $\cdot$ Single-

Molecule Magnet $\cdot$ Solvato-modulation

[1] R. Sessoli, D. Gatteschi, A. Caneschi, M. A. Novak, Nature 1993, 365 141-143.

[2] R. Sessoli, H. L. Tsai, A. R. Schake, S. Wang, J. B. Vincent, K. Folting D. Gatteschi, G. Christou, D. N. Hendrickson, J. Am. Chem. Soc. 1993 115, 1804-1816.

[3] N. Ishikawa, M. Sugita, T. Ishikawa, S. Koshihara, Y. Kaizu, J. Am. Chem Soc. 2003, 125, 8694-8695.

[4] D. N. Woodruff, R. E. P. Winpenny, R. A. Layfield, Chem. Rev. 2013, 113, 5110-5148

[5] J. Tang, P. Zhang, Lanthanide Single Molecule Magnets, Springer, 2015

[6] H. L. C. Feltham, S. Brooker, Coord. Chem. Rev. 2014, 276, 1-33.

[7] F. Pointillart, O. Cador, B. Le Guennic, L. Ouahab, Coord. Chem. Rev. 2017, 346, 150-175.

[8] F.-S. Guo, B. M. Day, Y.-C. Chen, M.-L. Tong, A. Mansikkamäki, R. A. Layfield, Science 2018, 362, 1400-1403.

[9] C. A. P. Goodwin, F. Ortu, D. Reta, N. F. Chilton, D. P. Mills, Nature 2017, 548, 439-442.

[10] M. Affronte, J. Mater. Chem. 2009, 19, 1731-1737.

[11] S. Thiele, F. Balestro, R. Ballou, S. Klyatskaya, M. Ruben, W. Wernsdorfer, Science 2014, 344, 1135-1138.

[12] K. S. Pedersen, A.-M. Ariciu, S. McAdams, H. Weihe, J. Bendix, F. Tuna S. Piligkos, J. Am. Chem. Soc. 2016, 138, 5801-5804.

[13] G. Serrano, L. Poggini, M. Briganti, A. L. Sorrentino, G. Cucinotta, L. Malavolti, B. Cortigiani, E. Otero, P. Sainctavit, S. Loth, F. Parenti, A.-L. Barra, A. Vindigni, A. Cornia, F. Totti, M. Mannini, R. Sessoli, Nat. Mater 2020, 1-6.

[14] M. Mannini, F. Pineider, C. Danieli, F. Totti, L. Sorace, P. Sainctavit, M. A. Arrio, E. Otero, L. Joly, J. C. Cezar, A. Cornia, R. Sessoli, Nature 2010 468, 417-421.

[15] C. Wäckerlin, F. Donati, A. Singha, R. Baltic, S. Rusponi, K. Diller, F. Patthey, M. Pivetta, Y. Lan, S. Klyatskaya, M. Ruben, H. Brune, J. Dreiser, Adv. Mater. 2016, 28, 5195-5199.

[16] Y. Kishi, F. Pointillart, B. Lefeuvre, F. Riobé, B. Le Guennic, S. Golhen, O. Cador, O. Maury, H. Fujiwara, L. Ouahab, Chem. Commun. 2017, 53, 3575-3578.

[17] M. Llunell, D. casanova, J. Cicera, J. M. Bofill, P. Alemany, S. Alvarez, SHAPE (version 2.1) 2013 
[18] G. Cucinotta, M. Perfetti, J. Luzon, M. Etienne, P.-E. Car, A. Caneschi, G. Calvez, K. Bernot, R. Sessoli, Angew. Chem., Int. Ed. 2012, 51, 16061610; Angew. Chem. 2012, 124, 1638-1642.

[19] M. Briganti, G. F. Garcia, J. Jung, R. Sessoli, B. Le Guennic, F. Totti, Chem. Sci. 2019, 10, 7233-7245.

[20] J. Jung, O. Cador, K. Bernot, F. Pointillart, J. Luzon, B. Le Guennic, Beilstein J. Nanotechnol. 2014, 5, 2267-2274.

[21] G. Cosquer, F. Pointillart, J. Jung, B. Le Guennic, S. Golhen, O. Cador, Y. Guyot, A. Brenier, O. Maury, L. Ouahab, Eur. J. Inorg. Chem. 2014, 2014, 69-82.

[22] Q. Zhou, F. Yang, B. Xin, G. Zeng, X. Zhou, K. Liu, D. Ma, G. Li, Z. Shi, S. Feng, Chem. Commun. 2013, 49, 8244-8246.

[23] F. Pointillart, J. F. Gonzalez, V. Montigaud, L. Tesi, V. Cherkasov, B. L. Guennic, O. Cador, L. Ouahab, R. Sessoli, V. Kuropatov, Inorg. Chem. Front. 2020, 7, 2322-2334.

[24] O. Cador, B. Le Guennic, F. Pointillart, Inorg. Chem. Front. 2019, 6, 3398-3417.

[25] F. Ma, J. Xiong, Y.-S. Meng, J. Yang, H.-L. Sun, S. Gao, Inorg. Chem. Front. 2018, 5, 2875-2884.

[26] D. Pinkowicz, H. I. Southerland, C. Avendaño, A. Prosvirin, C. Sanders, W. Wernsdorfer, K. S. Pedersen, J. Dreiser, R. Clérac, J. Nehrkorn, G. G. Simeoni, A. Schnegg, K. Holldack, K. R. Dunbar, J. Am. Chem. Soc. 2015, 137, 14406-14422.

[27] J.-Y. Ge, H.-Y. Wang, J. Li, J.-Z. Xie, Y. Song, J.-L. Zuo, Dalton Trans. 2017, 46, 3353-3362.

[28] J.-L. Liu, J.-Y. Wu, G.-Z. Huang, Y.-C. Chen, J.-H. Jia, L. Ungur, L. F. Chibotaru, X.-M. Chen, M.-L. Tong, Sci. Rep. 2015, 5, 16621.

[29] X. Zhang, V. Vieru, X. Feng, J.-L. Liu, Z. Zhang, B. Na, W. Shi, B.-W. Wang, A. K. Powell, L. F. Chibotaru, S. Gao, P. Cheng, J. R. Long, Angew. Chem., Int. Ed. 2015, 54, 9861-9865; Angew. Chem. 2015, 127, 9999-10003.

[30] K. Suzuki, R. Sato, N. Mizuno, Chem. Sci. 2013, 4, 596-600.

[31] J.-L. Liu, Y.-C. Chen, Y.-Z. Zheng, W.-Q. Lin, L. Ungur, W. Wernsdorfer, L. F. Chibotaru, M.-L. Tong, Chem. Sci. 2013, 4, 3310-3316.

[32] J.-Y. Ge, L. Cui, J. Li, F. Yu, Y. Song, Y.-Q. Zhang, J.-L. Zuo, M. Kurmoo, Inorg. Chem. 2017, 56, 336-343.

[33] A. Abragam, B. Bleaney, Electron Paramagnetic Resonance of Transition lons, Oxford University Press, Oxford, 2012.

[34] M. N. Leuenberger, D. Loss, Nature 2001, 410, 789-793.

[35] F. Ortu, D. Reta, Y.-S. Ding, C. A. P. Goodwin, M. P. Gregson, E. J. L. McInnes, R. E. P. Winpenny, Y.-Z. Zheng, S. T. Liddle, D. P. Mills, N. F. Chilton, Dalton Trans. 2019, 48, 8541-8545.

[36] T. T. da Cunha, J. Jung, M.-E. Boulon, G. Campo, F. Pointillart, C. L. M. Pereira, B. Le Guennic, O. Cador, K. Bernot, F. Pineider, S. Golhen, L. Ouahab, J. Am. Chem. Soc. 2013, 135, 16332-16335.

[37] F. Habib, P. H. Lin, J. Long, I. Korobkov, W. Wernsdorfer, M. Murugesu, J. Am. Chem. Soc. 2011, 133, 8830-8833.

[38] F. Pointillart, K. Bernot, S. Golhen, B. Le Guennic, T. Guizouarn, L. Ouahab, O. Cador, Angew. Chem., Int. Ed. 2015, 54, 1504-1507; Angew. Chem. 2015, 127, 1524-1527.

[39] J. Flores Gonzalez, H. Douib, B. Le Guennic, F. Pointillart, O. Cador, Inorg. Chem. 2021, 60, 540-544.

[40] S.-D. Jiang, B.-W. Wang, H.-L. Sun, Z.-M. Wang, S. Gao, J. Am. Chem. Soc. 2011, 133, 4730-4733.

[41] K. R. Meihaus, J. R. Long, J. Am. Chem. Soc. 2013, 135, 17952-17957.

[42] L. Ungur, J. J. Le Roy, I. Korobkov, M. Murugesu, L. F. Chibotaru, Angew. Chem. 2014, 53, 4413-4417; Angew. Chem. 2014, 126, 4502-4506.

[43] P. Zhang, L. Zhang, C. Wang, S. Xue, S.-Y. Lin, J. Tang, J. Am. Chem Soc. 2014, 136, 4484-4487.

[44] A. J. Brown, D. Pinkowicz, M. R. Saber, K. R. Dunbar, Angew. Chem., Int. Ed. 2015, 54, 5864-5868; Angew. Chem. 2015, 127, 5962-5966.

[45] M. A. AlDamen, S. Cardona-Serra, J. M. Clemente-Juan, E. Coronado, A. Gaita-Ariño, C. Martí-Gastaldo, F. Luis, O. Montero, Inorg. Chem. 2009, 48, 3467-3479.

[46] M. A. AIDamen, J. M. Clemente-Juan, E. Coronado, C. Martí-Gastaldo, A. Gaita-Ariño, J. Am. Chem. Soc. 2008, 130, 8874-8875.

[47] R. Shiozaki, A. Inagaki, A. Nishino, E. Nishio, M. Maekawa, H. Kominami, Y. Kera, J. Alloys Compd. 1996, 234, 193-198.
[48] M. Vonci, M. J. Giansiracusa, W. Van den Heuvel, R. W. Gable, B. Moubaraki, K. S. Murray, D. Yu, R. A. Mole, A. Soncini, C. Boskovic, Inorg. Chem. 2017, 56, 378-394.

[49] F. Luis, M. J. Martínez-Pérez, O. Montero, E. Coronado, S. CardonaSerra, C. Martí-Gastaldo, J. M. Clemente-Juan, J. Sesé, D. Drung, T Schurig, Phys. Rev. B 2010, 82, 060403.

[50] G. M. Sheldrick, Acta Cryst A 2015, 71, 3-8.

[51] G. M. Sheldrick, Acta Cryst C 2015, 71, 3-8.

[52] G. Kresse, J. Hafner, Phys. Rev. B 1993, 47, 558-561.

[53] G. Kresse, J. Hafner, Phys. Rev. B 1994, 49, 14251-14269.

[54] G. Kresse, J. Furthmüller, Comput. Mater. Sci. 1996, 6, 15-50.

[55] G. Kresse, J. Furthmüller, Phys. Rev. B 1996, 54, 11169-11186.

[56] J. P. Perdew, K. Burke, M. Ernzerhof, Phys. Rev. Lett. 1996, 77, 38653868.

[57] J. P. Perdew, K. Burke, M. Ernzerhof, Phys. Rev. Lett. 1997, 78, 13961396.

[58] S. Grimme, J. Antony, S. Ehrlich, H. Krieg, J. Chem. Phys. 2010, 132, 154104.

[59] P. E. Blöchl, Phys. Rev. B 1994, 50, 17953-17979.

[60] G. Kresse, D. Joubert, Phys. Rev. B 1999, 59, 1758-1775.

[61] F. Aquilante, J. Autschbach, R. K. Carlson, L. F. Chibotaru, M. G. Delcey, L. D. Vico, I. F. Galván, N. Ferré, L. M. Frutos, L. Gagliardi, M. Garavelli, A. Giussani, C. E. Hoyer, G. L. Manni, H. Lischka, D. Ma, P. Å. Malmqvist, T. Müller, A. Nenov, M. Olivucci, T. B. Pedersen, D. Peng, F. Plasser, B. Pritchard, M. Reiher, I. Rivalta, I. Schapiro, J. Segarra-Martí, M. Stenrup, D. G. Truhlar, L. Ungur, A. Valentini, S. Vancoillie, V. Veryazov, V. P. Vysotskiy, O. Weingart, F. Zapata, R. Lindh, J. Comput. Chem. 2016, 37, 506-541.

[62] B. O. Roos, P. R. Taylor, P. E. M. Sigbahn, Chem. Phys. 1980, 48, 157173.

[63] M. Douglas, N. M. Kroll, Ann. Phys. 1974, 82, 89-155.

[64] B. A. Hess, Phys. Rev. A 1985, 32, 756-763.

[65] B. A. Hess, Phys. Rev. A 1986, 33, 3742-3748.

[66] A. Wolf, M. Reiher, B. A. Hess, J. Chem. Phys. 2002, 117, 9215-9226.

[67] P.-O. Widmark, P.-Å. Malmqvist, B. O. Roos, Theoret. Chim. Acta 1990 77, 291-306.

[68] B. O. Roos, R. Lindh, P.-Å. Malmqvist, V. Veryazov, P.-O. Widmark, J. Phys. Chem. A 2004, 108, 2851-2858.

[69] B. O. Roos, R. Lindh, P.-Å. Malmqvist, V. Veryazov, P.-O. Widmark, J. Phys. Chem. A 2005, 109, 6575-6579.

[70] P. A.. Malmqvist, B. O. Roos, B. Schimmelpfennig, Chem. Phys. Lett. 2002, 357, 230-240.

[71] L. F. Chibotaru, L. Ungur, J. Chem. Phys. 2012, 137, 064112.

[72] F. Aquilante, P.-Å. Malmqvist, T. B. Pedersen, A. Ghosh, B. O. Roos, J. Chem. Theory Comput. 2008, 4, 694-702. 
WILEY-VCH

\section{Entry for the Table of Contents}

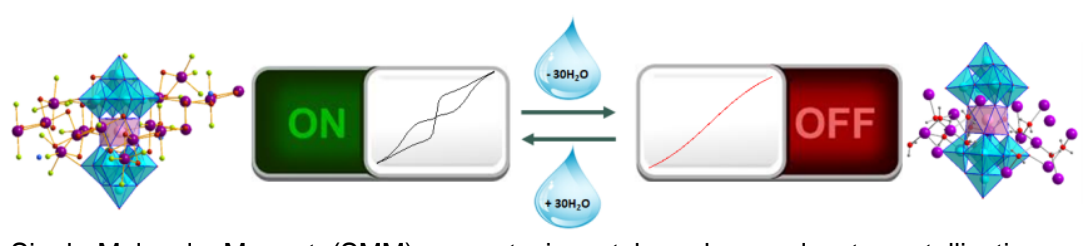

Single-Molecule Magnet (SMM) property is not based on solvent crystallization molecules but hydrated polyoxometallate(POM)-based $\mathrm{Na}_{9}\left[\mathrm{Er}\left(\mathrm{W}_{5} \mathrm{O}_{18}\right)_{2}\right] \cdot 35 \mathrm{H}_{2} \mathrm{O}$ and dehydrated form relax differently. Experimental and theoretical investigations evidence that the stability of the edifice depends on labile water molecules. Furthermore, isotopic enrichment at Er"ll site shows that the relaxation dynamics in the quantum regime depends on the nuclear spin.

@BGuennic

@PointillartF

@KevinBernot

@chimie_ISCR 